\title{
STUDY ON PROPERTIES OF CONCRETE WITH DIFFERENT LEVELS OF REPLACEMENT OF CEMENT BY FLY ASH
}

\author{
Nagabhushana ${ }^{1}$ \\ ${ }^{I}$ Associate Professor of Civil Engineering, JSS Academy of Technical Education, Bangalore-560060
}

\begin{abstract}
Concrete is a widely used construction material which contains four major ingredients such as coarse aggregate, fine aggregate, cement and water. The consumption of concrete is increasing every year with the number of developmental activities in infrastructure sector. The production of cement involves high energy consumption. Hence, there is a need to reduce the consumption of cement in concrete by using other alternate materials which posses cementitious properties. Fly ash is one such material which can be used as a replacement to cement in concrete. The present study aims in observing the variation of strength of different grades of concrete with different levels of fly ash replacement. The objective of the study is to re-establish the findings of earlier research done in the area of fly ash concrete. The grades of concrete selected for the study are M20, M35 and M50. The fly ash replacements considered for the study are 0\%, 20\%, 35\% and 50\% of cement by weight. The results of this study indicates that for M20 and M35 grades of concrete, there is increase in strength with 35\% cement replacement by fly ash. For M50 grade of concrete, there is decrease in strength for all replacement levels selected for the study.
\end{abstract}

Keywords: Concrete, Cementitious material, Fly ash.

\section{INTRODUCTION}

Cement is a costly component of concrete. Even though, it is available without any scarcity, it involves high energy consumption for it's production. Hence, it is advisable to minimize the use of cement. However, concrete is a highly versatile construction material because of it's strength, durability and mouldability. Therefore, it is highly worthful to search for an alternate material which can replace cement without compromising the quality of concrete. Fly ash is one such material which is considerably cementitious in nature [1]. There are many research findings to support the use of fly ash in producing concrete. In one of the earlier research, it is observed that even though there is small reduction in strength at 28 days, there is considerable increase in strength at 90 days of curing [2]. There is improvement in workability of concrete due to increased cohesiveness when fly ash is used as a replacement of cement up to $30 \%$ [3]. When concrete contains $20 \%$ of fly ash as replacement to cement, there is improved strength at the age of 56 days [4]. The fly ash particles are nearly spherical in shape and hence it results in more cohesive mix with no sign of segregation and bleeding [5]. When a part of cement is replaced by fly ash, the durability of concrete gets enhanced [6]. When fly ash is used in nano size, there is formation of C-S-H (Calcium Silicate Hydrate) which improves the strength of concrete [7]. In the present study, it is examined to use fly ash as a replacement to cement. For the purpose of study, three grades of concrete are selected (M20, M35 and M50). Also, four levels of replacement of cement by fly ash are considered $(0 \%, 20 \%, 35 \%$ and $50 \%)$. For each grade of concrete and for each replacement level, various strength properties such as compressive strength, split tensile strength and flexural strength are observed at 28 days of curing period.

\subsection{Materials Used}

(a) Cement: Ordinary Portland Cement(OPC) of 53 grade conforming to IS $12269-1987$ has been used

(b) Sand: The normal sand used for the study is tested as per IS 383-1970. The value of specific gravity is 2.4 , bulk density is $1660 \mathrm{~kg} / \mathrm{m}^{3}$ and fineness modulus is 2.56 .

(c) Water: Clean, potable water was used.

(d) Coarse aggregate: The Coarse aggregate of maximum size of $20 \mathrm{~mm}$ has been used. The value of specific gravity is 2.7. The material is retained on IS480.

(e) Fly ash Class F fly ash is used in this study. Fly ash is a waste product generated in thermal power plants [8]. During the combustion of pulverized Coal in thermal power plants, the volatile matter is vaporized and the majority of Carbon is burnt off. The mineral matter associated with coal such as Clay, quartz and felsbar will disintegrate to varying degree. This unburnt Carbon is collected as ash. The coarser particles fall in the bottom of the furnace. The finer particles are collected using cyclone separators. It is termed as 'fly ash'.

For the present study, fly ash obtained from Raichur Thermal Power Corporation (RTPC) is used. It falls under Class F category, as per ASTM (American Society for Testing of Materials) classification. It constrains Cao less than $10 \%$.

\section{EXPERIMENTAL INVESTIGATIONS}

The object is to study the strength properties of M20, M35 and M50 grades of concrete with various levels of replacement of cement by fly ash and to arrive at optimum 
percentage of fly ash content which gives higher strength. The experimental investigation includes determination of compressive strength, split tensile strength and flexural strength of all the selected grades of concrete with various levels of replacement of cement by fly ash. The replacement levels selected for the study are $0 \%, 15 \%, 35 \%$, and $50 \%$ of cement by weight.

The Mix proposition is done as per IS 10262-2009[9]. The proportions of various ingredients of concrete are shown in Table 1.

Table 1 Proportions of materials for M20, M35 and M50 grades of normal concrete

\begin{tabular}{|l|l|l|l|l|l|}
\hline $\begin{array}{l}\text { Sl } \\
\text { n } \\
\text { o }\end{array}$ & $\begin{array}{l}\text { Grade } \\
\text { of } \\
\text { concret } \\
\text { e }\end{array}$ & $\begin{array}{l}\text { Cemen } \\
\text { t }\end{array}$ & $\begin{array}{l}\text { Fine } \\
\text { aggregat } \\
\text { e }\end{array}$ & $\begin{array}{l}\text { Coarse } \\
\text { aggreg } \\
\text { ate }\end{array}$ & $\begin{array}{l}\text { Wate } \\
\text { r- } \\
\text { ceme } \\
\text { nt } \\
\text { ratio }\end{array}$ \\
\hline 1 & M20 & 1 & 1.41 & 3.21 & 0.5 \\
\hline 2 & M35 & 1 & 0.95 & 2.36 & 0.38 \\
\hline 3 & M50 & 1 & 1.50 & 2.50 & 0.39 \\
\hline
\end{tabular}

For M20 grade, workability is achieved without super plasticizer. However, for M35 and M50 grades, required quantity of super plasticizer was added to get workable concrete. The compressive strength specimen is of size $150 \mathrm{~mm} \times 150 \mathrm{~mm} \times 150 \mathrm{~mm}$. The split tensile strength specimens are of diameter $150 \mathrm{~mm}$ and height $300 \mathrm{~mm}$. The flexural strength specimen are beams of dimension $100 \mathrm{~mm}$ x $100 \mathrm{~mm}$ x 500mm. Beam specimens were tested with twopoint loading with an effective span of $400 \mathrm{~mm}$.

The specimens were tested at the age of 28 days of curing. The procedure as described in IS 516-1959 (Indian Standard Methods of test for Strength of Concrete) [10] is followed for all the tests.

\section{RESULTS AND DISCUSSIONS}

The results of the present investigation are presented in this section. Table 2 gives compressive strength of M20, M35 and M50 grades of concrete with various levels of replacement of cement by fly ash. Table 3 gives split tensile strength of these grades of concrete. Table 4 gives flexural strength of these grades of concrete.

Fig 1 shows variation of 28 day compressive strength of the concrete with different percentage of replacement of cement by fly ash. Fig2 shows the corresponding variation of split tensile strength Fig 3 shows the variation of flexural strength of concrete.

From the result of this investigation, the following observations are made.

For M20 grade of concrete, the 28 days compressive strength is increased by $8 \%$ when compared to normal concrete with $35 \%$ replacement of cement. At $50 \%$ replacement of cement by fly ash, there is decrease in strength. The increase in split tensile strength at 35\% replacement is $14 \%$. The increase in flexural strength at $35 \%$ replacement is $8 \%$ when compared to normal concrete. For M35 grade of concrete the 28 days compressive strength is increased by $7 \%$ when compared to normal concrete at $35 \%$ replacement of cement. The increase in split tensile strength is $12 \%$. The increase in flexural strength is $28 \%$ with respect to normal concrete.

Table 2: Compressive strength of M20, M35 and M50 grades of concrete with various levels of replacement of cement by fly ash.

\begin{tabular}{|c|c|c|c|}
\hline $\begin{array}{l}\text { Sl } \\
\text { no }\end{array}$ & $\begin{array}{l}\text { Specimen } \\
\text { designation }\end{array}$ & $\begin{array}{l}\text { Fly ash } \\
\text { Replacement } \\
\text { in \% }\end{array}$ & $\begin{array}{l}\text { 28days } \\
\text { strength } \\
\mathrm{N} / \mathrm{mm}^{2}\end{array}$ \\
\hline \multicolumn{4}{|c|}{ M20 concrete } \\
\hline 1 & M20-NC & 00 & 36.37 \\
\hline 2 & M20-FARC-20 & 20 & 38.87 \\
\hline 3 & M20-FARC-35 & 35 & 39.38 \\
\hline 4 & M20-FARC-50 & 50 & 24.30 \\
\hline \multicolumn{4}{|c|}{ M35 concrete } \\
\hline 5 & M35-NC & 00 & 45.19 \\
\hline 6 & M35-FARC-20 & 20 & 47.45 \\
\hline 7 & M35-FARC-35 & 35 & 48.35 \\
\hline 8 & M35-FARC-50 & 50 & 35.25 \\
\hline \multicolumn{4}{|c|}{ M50 concrete } \\
\hline 9 & M50-NC & 00 & 56.68 \\
\hline 10 & M50-FARC-20 & 20 & 45.34 \\
\hline 11 & M50-FARC-35 & 35 & 42.51 \\
\hline 12 & M50-FARC-50 & 50 & 30.96 \\
\hline
\end{tabular}

Table 3: Split tensile strength of M20, M35 and M50 grades of concrete with various levels of replacement of cement by fly ash

\begin{tabular}{|l|l|l|l|}
\hline SI no & $\begin{array}{l}\text { Specimen } \\
\text { designation }\end{array}$ & $\begin{array}{l}\text { Fly ash } \\
\text { Replacement } \\
\text { in \% }\end{array}$ & $\begin{array}{l}\text { 28days } \\
\text { strength in } \\
\text { N/mm }\end{array}$ \\
\hline \multicolumn{2}{|l|}{ M20 concrete } & 00 & 2.66 \\
\hline 1 & M20-NC & 2.57 \\
\hline 2 & M20-FARC-20 & 20 & 3.04 \\
\hline 3 & M20-FARC-35 & 35 & \\
\hline
\end{tabular}




\begin{tabular}{|l|l|l|l|}
\hline 4 & M20-FARC-50 & 50 & 2.15 \\
\hline \multicolumn{4}{|l|}{ M35 concrete } \\
\hline 5 & M35-NC & 00 & 3.25 \\
\hline 6 & M35-FARC-20 & 20 & 3.19 \\
\hline 7 & M35-FARC-35 & 35 & 3.63 \\
\hline 8 & M35-FARC-50 & 50 & 2.48 \\
\hline M50 concrete & & \\
\hline 9 & M50-NC & 00 & 4.89 \\
\hline 10 & M50-FARC-20 & 20 & 3.83 \\
\hline 11 & M50-FARC-35 & 35 & 3.57 \\
\hline 12 & M50-FARC-50 & 50 & 2.61 \\
\hline
\end{tabular}

Table 4 Flexural strength of M20, M35 and M50 grades of concrete with various levels of replacement of cement by fly

\begin{tabular}{|l|l|l|l|}
\hline $\begin{array}{l}\text { SI } \\
\text { no }\end{array}$ & $\begin{array}{l}\text { Specimen } \\
\text { designation }\end{array}$ & $\begin{array}{l}\text { Fly ash } \\
\text { Replacement } \\
\text { in \% }\end{array}$ & $\begin{array}{l}\text { 28days } \\
\text { strength in } \\
\text { N/mm }\end{array}$ \\
\hline M20 concrete & 00 & 5.20 \\
\hline 1 & M20-NC & 20 & 5.47 \\
\hline 2 & M20-FARC-20 & 5.60 \\
\hline 3 & M20-FARC-35 & 35 & 4.07 \\
\hline 4 & M20-FARC-50 & 50 & 6.13 \\
\hline M35 concrete & & 7.47 \\
\hline 5 & M35-NC & 00 & 7.87 \\
\hline 6 & M35-FARC-20 & 20 & 5.60 \\
\hline 7 & M35-FARC-35 & 35 & 6.83 \\
\hline 8 & M35-FARC-50 & 50 & 6.89 \\
\hline M50 concrete & & 6.24 \\
\hline 9 & M50-NC & 00 & 20 \\
\hline 10 & M50-FARC-20 & 20 & \\
\hline 11 & M50-FARC-35 & 35 & 50 \\
\hline 12 & M50-FARC-50 & 50 & \\
\hline
\end{tabular}

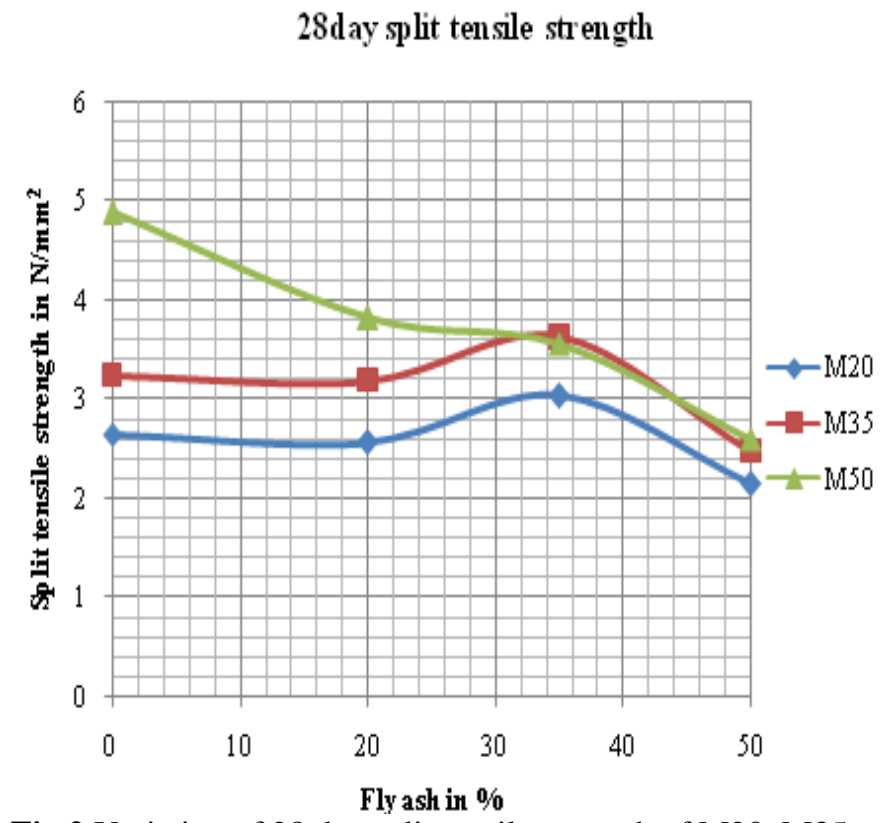

Fig 2 Variation of 28 day split tensile strength of M20, M35 and M50 concretes with different percentage of replacement of fly ash 


\section{8day flexural strength}

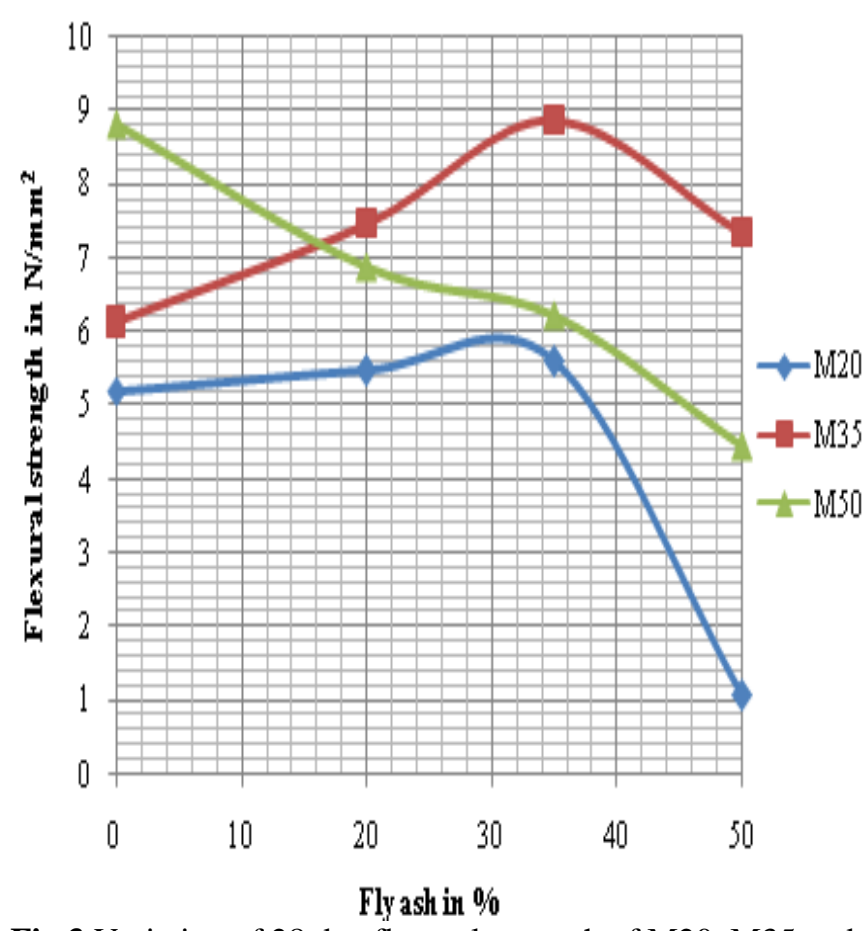

Fig 3 Variation of 28 day flexural strength of M20, M35 and M50 concretes with different percentage of replacement of fly ash.

For M50 grade of concrete the 28 days compressive strength is found to be decreasing when compared to normal concrete. It is $80 \%, 75 \%$ and $55 \%$ of strength of normal concrete with cement replacement of $20 \%, 35 \%$ and $50 \%$. The corresponding values of split tensile strength are $78 \%$, $73 \%$ and $53 \%$ of normal concrete. The corresponding values of flexural strength are $78 \%, 71 \%$ and $51 \%$ with the cement replacement of $20 \%, 35 \%$ and $50 \%$ respectively.

\section{CONCLUSION}

From the result of this study, it can be concluded that cement replacement by fly ash is useful in lower grades of concrete such as M20 and M35. It can be stated that at 35\% of replacement of cement by fly ash, there is considerable increase in strength properties. Hence, $35 \%$ replacement can be considered as optimum replacement level to get enhanced strength. Also, it can be concluded that replacement of cement by fly ash is not suitable for higher grades of concrete such as M50. It results in decreased value of strength properties for the selected replacement levels of cement by fly ash.

\section{REFERENCES}

[1] Ganesh Babu K and Siva Nageswara Rao(1995)"Efficiency of fly ash in concrete", Cement and Concrete research, Vol.26,No.3,Dec 1995.

[2] S.L Patil, J N Kale, S Suman(2012) "Fly ash concrete- A technical analysis for compressive strength" , International journal of advanced engineering research and studies, Vol 2, No1, December-2012.

[3] Heba A Mohamed (2011) “ Effect of fly ash and silica on compressive strength of self compacting concrete" Vol. 2 No. 2, Ain Shams engineering journal, june 2011.

[4] Alvin Harison, Vikas Srivastava and Arpan Herbert (2014) "Effect of fly ash on compressive strength of Portland pozzolona cement concrete", journal of academia and industrial research(JAIR), Vol.2, No.8, January-2014.

[5] N Nagabhushana and H Sharada Bai (2011) Use of Crushed rock powder as replacement of fine aggregate in mortar and concrete, Indian J. Science and Technology, Vol4, No. 8 , 917-922.

[6] A.K Mullick (2005) "Use of fly ash in structural concrete", Indian concrete journal, Vol.19, No.6 June-2005.

[7] S. Yuvaraj, Suji mohan kumar, N Dinesh, C Karthic (2012) "Experimental research on improvement of concrete strength and enhancing the resisting property of corrosion and permeability by the use of nano silica fly ashed concrete", International journal of emerging technology and advanced engineering, Vol.2, No.6, June-2012.

[8] Freeda christy and Tensing.D(2010)"Effect of classF fly ash as partial replacement with cement and fine aggregate in mortar", Indian journal of Engineering and material science, Vol.17,No.4,April 2010.

[9] IS 10262-2009, Indian Standard recommended guidelines for concrete mix design, Bureau of Indian standards, New Delhi.

[10] IS 516-1959, Indian standard methods of test for strength of concrete, Bureau of Indian standards, New Delhi.

\section{BIOGRAPHY}

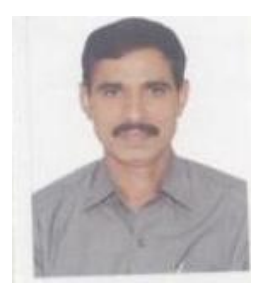

Dr. Nagabhushana has completed B.E and M.Tech degree from Mysore University and $\mathrm{PhD}$ from Bangalore University. He has more than 20 years of experience in teaching. He has published research papers in international journals. Presently, he is working as associate Professor of Civil engineering at J.S.S Academy of Technical Education, Bangalore. 